\title{
XXIX. A letter to J. E. Bicheno, Esq., F.R.S., in examination of his paper "On Systems and Methods" in the Linnean Transactions
}

\section{W. S. MacLeay Esq. A.M. F.L.S.}

To cite this article: W. S. MacLeay Esq. A.M. F.L.S. (1829) XXIX. A letter to J. E. Bicheno, Esq., F.R.S., in examination of his paper "On Systems and Methods" in the Linnean Transactions, Philosophical Magazine Series 2, 6:33, 199-212, DOI: 10.1080/14786442908675120

To link to this article: http://dx.doi.org/10.1080/14786442908675120

曲 Published online: 14 Jul 2009.

Submit your article to this journal $[\pi$

Џll Article views: 2

Q View related articles $\longleftarrow$

Citing articles: 1 View citing articles $\square$ 
Species.

Icon.

27. Xyl.Hyperici, Fab.. ... Ernst, VI. Pl. CCXLII. f. 357.

28. - Perspicillaris, Linn. Ernst, VI. PI. CCXXXVI.f.345.

29. - Platyptera, Esper. Ernst, VII. Pl. CCXCI. f. 490.

30. - Radiosa, Esper.... Hübn.Noct.Tab.92.f. 434.(fœm.)

31. - Antirrhini, Hübn. Ernst, VI.Pl.CCXXXVII.f.347. e. $f$.

32. - Linaria, Fab.....

Ernst, VI.PI.CCXXXVII.f. 347. a-d.

33. - Opalina, Hübn...

Hübn.Noct.Tab. 81.f.376. (fœm.)

34. - Delphinii, Linn.* Ernst, VIII. Pl. CCCX. f. 538.

Curtis, Brit. Ent. II. Pl.76. Larva et Imago.

[To be continued.]

XXIX. A Letter to J. E. Bicheno, Esq., F.R.S., in examination of his Paper "On Systems and Methods" in the Linnean Transactions. By W. S. MacLeay, Esq., A.M., F.L.S., \&.c.†

My dear Sir,

I HAVE read your Paper "On Systems and Methods," in the Linnean 'Transactionst, with some degree of interest, as it derives no small importance from being, as every word shows, clearly written ex cathedrâ. With a few exceptions, which I should hope have proceeded from inadvertency, it is, moreover, upon the whole, a liberal exposition of the opinions pre-

males : wings slightly deflexed during repose; anterior obscurely denticulate on the hinder margin: in general of gay colours, sometimes with pale reticulations, and mostly with a pale undulated striga, in which is usually a conspicuous angulation, resembling the letter W, near the posterior margin; stigmata distinct; posterior wings with an obseure emargination towards the costa: larva naked, generally of lively colour : pupa subterranean."-Steph. Haust. II. p. 179.

* Cirariclea, Steph. Curtis.

"Antenne long setaceous, composed of numercus short joints covered with scales above, hairy beneath, lst joint large, concealed by long, hairy scales. Labrum and mandibles attached to the clypeus. Maxillee nearly as long as the body, with a few glands like tentacula towards the apex. Labial palpi rather short, curved upward, covered entirely with long hairy scales, 3-jointed, 1st joint long, cylindric, 2nd shorter, somewhat ovate, 3rd small ovate. Head trigonate viewed from above. Abdomen without tufts of scales, apex of the male slightly bifid. Wings deflexed, superior somewhat lanceolate, inferior rather small. , Citia very long. Legs clothed with soft hair, anterior rather short. Tibia, anterior very short, trigonate, with 2 horny naked spines at the apex, the internal one being very long and curved. Tarsi 5 -jointed, armed with rows of spines beneath, 1 st being very long. Claws minute, bifid. Pulvilli distinct. Caterpillars with 6 pectoral, 8 abdominal and 2 anal feet."-Curtis, l.c.

+ From the Zoological Journal, vol. iv. p. 402.

$\ddagger$ Vol. xv. p. 471.-See Phil. Mag. and Ann. vol. iii. p. 213. 
valent among the Naturalists of the old Linnean school. True it is, you think it necessary to show your impartiality, and to bestow some censure en passant on this school, but it requires no great penetration to see that your Paper was intended for their peculiar circle, and I therefore earnestly trust that your labours may not go unrewarded, and that you may obtain all the honour and glory which you promised yourself from the stauneh Linneans, by this publication.

I know enough of you to be convinced, that although, from the style of your Paper, you seem to wish to lay down your "principles of arrangement" oracularly, still, rather than that your laws should be wholly slighted, you would be most willing, nay, desirous to have them well sifted and examined. I am convinced, I repeat, that you have too firm an opinion of their soundness to believe for a moment, that they will not come like pure gold from any crucible in which they may be assayed. Perhaps other friends who have the pleasure of being nearer to you, have long ere this shown you your mistake; but in case they have not, I am sure that you will not be surprised that I should have determined to state how far I feel myself called upon to agree with you in opinion.

My review of your paper must be premised with the remark, that $I$ do not pretend to combat the general conclusion to which it is your object to arrive; for I confess, that after having twice carefully read over your argument, I am not sure that I understand its drift, and much less am I certain, that if I did understand it, your sentiments would differ considerably from my own. If, however, the purport of your Paper $\mathrm{be}$, as there is some reason to suspect, comprehended in the assertion, that "the danger to be now apprehended is, that those who adopt other arrangements" than the Linnean, "will forget the advantages to be derived from what is old in their love of that which is new," then I would once for all observe, that there never was a time when Naturalists paid more attention to the labours of their predecessors, whether ancient or modern, than at present: and therein indeed consists a part of their diagnosis, as you would perhaps express it, from the school which you advocate; and which in its love and veneration for what is not old, but only Linnean, remains in a total and complete ignorance of whatever has not proceeded from the pens of the Swede and his most servile admirers.

Still, nevertheless, since I remain in doubt as to this being the object you had in view in writing on Systems and Methods, I shall confine myself strictly to those of your propositions which I think most difficult to assent to, leaving the general conclusion at which you would arrive, unless it be as above, 
above, untouched, until you shall have, at some future period, more clearly expressed it.

You say that you are not yourself opposed to any particular system, but only intend in your Paper to lay down some "first principles of arrangement," to serve as a test by which Naturalists may try all systems. Let us, however, examine calmly these "first principles" themselves, before we apply them; for the test of a system ought surely to be proved good and true before we can allow it to regulate either our assent or dissent.

In the first place, you propose to treat the subject metaphysically, as a Locke, not as a Linnæus. Now to this proposal no Naturalist ought to object, provided you found your metaphysical arguments, and "abstract reasoning," on some little observation of Nature, and provided you illustrate your various positions by facts drawn from Natural History. How far your Paper is strictly logical or metaphysical, I will not now discuss; but $I$ will venture to say that your abstract reasoning would have carried much more weight with it, had you seasoned it a little more with illustrations drawn from observed facts.

You are pleased, upon the authority of Mr. Roscoe and Sir J. Smith, which you very naturally esteem quite conclusive, to state to those who break up the old genera into many new ones, "that the artificial and natural systems aim at two very distinct objects." Although in these degenerate days it is not very usual to talk of the natural system as aiming at an object, I imagine that I understand what you would say, in which case the information you would impart is not very original either from your botanical authorities or yourself; nor am I aware exactly for whom you are charitable enough to intend it, as I know of no. Naturalist who does break up, at least in your sense of the words, the old oxders and genera when he deems them good. I say in your sense of the words, for I must suppose you mean your advice for those who destroy or take no notice of the ancient groupes. You cannot surely, with your talents for abstract reasoning, mean to attack those who not merely preserve them, but by subdivision make us by the consequent analysis better acquainted with their internal construction. A person who retains the groupes of the older Naturalists, and moreover shows us how these may be resolved again into others, evidently possesses a greater portion of that acquaintance with individual forms upon which our knowledge of the natural system must, as even you yourself allow, eventually be grounded. I cannot believe that you, who profess to understand the exact portion of merit that be-

N. S. Vol, 6. No. 33. Sept. 1829.

$2 \mathrm{D}$ longs 
longs respectively to the various schools of Naturalists, now require to be informed that those of the present day make it a rale to preserve the ancient groupes where they deem them good, and only differ from their predecessors in showing how these groupes may be subdivided. This, in fact, is the real progress of Natural History; for on looking back at the mode for instance, in which Zoology has advanced, we find that Aristetle's Genera were the Orders of Linnæus, and that the Genera of Linnæurs are the Families of the present day. And not only the word genus, but even the word species, as you yourself say, has become more confined in its signification. To say that the word genus had originally any confined or determinate sense given to it by Linrious, or that any particular limits were assigned to it by him, beyond that perhaps of its being his smallest known groupe of species, is sufficiently disproved, not only by the impossibility of his making it to signify any thing else than a groupe, but also by the fact, that the learned Swede was constantly, as his knowledge of individuals increased, subdividing his early genera into new ones. But however this may be, I beg you may rest assured that every person who goes on increasing his acquaintance with the smaller natural groupes, whether they be called genera, or sulgenere, or any thing else, must know but too well that artificial systems aim at a different dbject from the natural system. I should have fancied, indeed, that so much was implied by the bare use of such terms as natural and artificial.

An artificial system aims at facilitating the distinction and nomenclature of species, and not at the knowledge of how these species are connected together in the one great plan of creation, which in fact is the enatural system. An artificial system, therefore, really aims at an object; but the natural system is itself the object aimed at by those, who truly know the difference between the two, and how trivial and contemptible the most perfect acquaintance with the one is in comparison with the smallest glimpse of the other. But you state that the natural system has an object, namely, "6 to abridge the fatbour of reasoning!"' If I know what is meant by the Natural 'System, it is as I have already stated, the original plan of the creation; and to say, therefore, that the object of the natural system, or rather of the Deity who devised it, was to abridge the labour of reasoning, is beyond my comprehension, and still less can I understand how it answers to the purpose thus assigned to it. I strspect, indeed, the longer you stady it, the less you will find your labour abridged. At least such is the recorded experience of men who have dealt as much in the observation of facts as in abstract reasoning. 
You favour us with the Linnean definition of a species, and then think proper to throw doubt on its accuracy, because, as I conceive, you happened not at the moment to turn over a page or two more of the Philosophia Botanica. I am not sufficient Botanist; perhaps, to understand the difficulties which appear to have beset you in the particular department of $\mathrm{Na}$-: tural History which you have studied; but I may state, that when similar difficulties occur in Zoology, and species are ascertained "to run one into another," we are accustomed to doubt the fact of their being distinct species; we call them varieties, and search for some general characteristic which will include and insulate the whole of these varieties, and then call that the specific character. If I may trust the evidence of my eyes, the White and Negro races of the human species "run. into one another by imperceptible shades, unappreciable by human sense, so as to render it impossible to circumscribe them." Nay, there are "empirical clanacters" which distinguish even a Frenchman from an Englishman, and "s wich. can only be perceived by long and familiar experience, and cannot be described by words; yet no one hitherto has been bold enough to declare them distinct species, It seems, nevertheless, that there are certain persons " who think it advisable to break up" the old species into many new ones; but you evidently consider such persons as angels in comparison to the wretches who would dare to subdivide a Linnean genus, a crime which you have ever held in the utmost abhorrence. Yet, as I understand the matter, if there be any groupe in Natural History more truly insulated than another, it a species; and the division of this natural groupe of individuals ought scarcely, therefore, to be less blamed than that of a genus which may have only rested on the good pleasure or ignorance of Linnæus, or on that of some blind worshipper of his infallibility. Not indeed that I would have those poor species-makers attacked; for I care very little one way or the other about them, although for all that I know, even they may. be doing good in their generation, by pointing out differences.

By the bye, on the subjeet of Species you settle the question by deciding that 6 in cases of difficulty the assumed law onght to be brought to the test of experiment, or the species should be rejected." Now I find it to be a case of some difficulty to understand this advice, since on looking back, the only 6 as sumed law" I can perceive mentioned is as follows: "A species shall be that distinct form originally so created, and producing, by certain laws of generation, others like itself;" and. unfortunately you bave forgotten to inform us how we are to ascertain by experiment, "a distinct form originally so cre- 
ated." This, however, is clearly the essential characteristic laid down in the law, since a Negro "produces by certain laws of generation others like himself," and yet is not very generally accounted to be a distinct species. But I ought to recollect, that in spite of Mr. Wilberforce, you have your doubts on this particular point: that in fact it still remains with you "the most difficult problem of all."

You lay down as a "first principle of arrangement," that " in Botany the characters of a Genus should be taken from the parts of fructification, and in Zoology from such parts as are indicative of structure and habits." Having myself, as you know, dabbled a little in Zoology, and being pleased with the sight of a really new definition, $I$ am anxious to learn what other zoological parts remain, in order that I may avoid them.

To clear up the fog in which our poor brains are enveloped when we attempt to distinguish a species from a genus, you next : inform us that "there is the same difference between a genus and a species as instruments of reasoning, as between a definition and a proposition in geometry." Now the difference between the latter is, that the proposition requires demonstration, and the definition not. I must therefore suppose that this mode of illustration is "ut lucus a non lucendo," for you have just before declared that species must " be brought to the test of experiment," in other words, must be demonstrated.

It appears you do not regard genera as merely conventional; but as actually founded in nature, as well as species. I likwise consider genera when properly defined, to be founded in nature, as I have elsewhere said; * but I have not found even these natural genera, upon the whole, to be so distinctly insulated from each other as species. I will now, however, go further than you, by stating that the groupes you object to, such as Class, Order, Tribe, Cohort, and Family, are, when properly defined, just as natural as Genera; and also that the higher we ascend in the scale, and the more comprehensive our groupes are, we may, in general, be assured, that in the same proportion they are perhaps even more natural. Thus, who will assert that Animals form a less natural groupe than Vertebrata, Vertebrata than Mammalia, Mammalia than Cetacea, or these last than the genus Balæna? Even Linnæus, the infallible Linnæus, speaks of natural classes and natural orders as distinct from artificial ones. No one, till now, has ventured to call the classes of Mammalia, Birds and Fishes, or the orders Lepidoptera, Coleoptera and Diptera, "gratuitous assumptions." Your doctrime, therefore, is really original ;

* See Horæ Entomologicæ, page 490. 
but at the same time it is rather surprising that the recognized organ of the Linnean Society should publicly, in the Transactions of that learned body, state that the above " different gradations are gratuitous assumptions with which Nature has nothing to do "' and that pursuing this doctrine, he should object, not merely to those who would "attempt to express with more accuracy larger generalizations than they, would do by employing a generic term," but also bestow censure on those "who think it advisable to break up the old genera into new ones." In short, we must remain stationary, according to you, with neither greater nor less groupes of species than the genera of Linnæus and Sir James Smith. All other assemblages of approximations, and approximations of assemblages, " are rather predicated than proved;" and in future we are only to be permitted by you "to point them out by mere signs, such as are used in printing," by asterisks, forsooth, and obelisks, or a casual dagger. Such is the perfect vehicle which in future is to convey with precision the just relation of things! I trust that you will favour us yourself with a specimen of it, and show that you know how, by example, to enforce your precepts.

You do not seem to think those persons who regard genera subject to be broken down to suit their convenience, as entitled to make use of the word Genus. It is a downright robbery on their part. "They would do well to employ some other term, else one great object will be lost at which we are aiming; - the keeping together under one common head those small assemblages of species which in some instances are so obvious and so important." On this head I experience great pleasure in being able to allay your fears, and to assure you that they do keep together under a common head, all those small assemblages of species which they conceive to be obvious; and that they even go further (too far you will say), and keep together the large assemblages also.

I now come to one of those illustrations with which you have so sparingly sprinkled your Paper, no doubt from reluctance to increase its bulk; and I find that "it would be the height of folly to give up the term of Genus for such insulated groups as Erica, Rosa, and Eriocaulon among plants, and Vespertilio, Strix, and Scarabæus among animals." If there be pleasure in being able to meet you on a known arena, I may also be expected to experience fear in having to defend myself against one who enters the lists so cavalierly. There is nothing like presenting an imposing front on the first attack where boldness is often of more avail than strength of weapons. No doubt it was from contempt for a strong example, that you chose your present zoological weapons, and therefore 
it wonld be presumption in me to tell you that upon a little deeper acquaintance with Zoology, you will see that neither Vespertilio, Strix, nor Scarabæus, as defined by Linnæus, are insulated groupes. As to Scarabæus, indeed, I should be glad to know by what characters you would insulate it happen to have seen more than 2000 species of the Linnean geats: Scarabæus; when Linnæus himself saw little more than 80 , I suspect, therefore, that I have given quite as much time and attention to the consideration of this Linnean genus as your although you, by a species of intuition, have got the start of me. This must be my apology for daring still to brave your polite imputation of having arrived at the acme of folly, and for still imagining that $I$ have done some service to Entomology in helping to subdivide so immense a groupe. You are truly the first of naturalists, and I dare say will also bave the honour of being the last, who has written on Searabrus, and pronounced it to be an insulated groupe. Perhaps it was from their being so little abstract, and their descending so low as to study the subject in nature, that those plodding entomologists, Fabricius and Iatreille, have had such difficulty in finding a place for Sinodendron, Lethrus, \&c., \&c. As you profess, two or three pages after, to look at Entomology with the eye of a master, and to point out the difficulties and defects of the science, you could not surely be ignorant that Fabricius, whom Linnæus called his master in Entomology, that. Latreille, Olivier, and Kirby, that in short every molem Entomologist who does not belong to what may be termed the defunct or dying Linmean school of England, has found it necessary to subdivide the Linnean genus Scarabæus. The chair, therefore, of the Secretary of the Linmean Society, must be placed on some peculiarly high eminence, when it entitles a gentleman on the strength of having described three species of Orchis, and perhaps twice as many Rushes, to dismiss all Entomologists subsequent to Linnæus with the compliment of being: a pack of fools.

It is to be regretted, that so oracular an authority on $\mathrm{Sy} \rightarrow$ stems and Methods should not have shown wherein they differ from each other. It only remains for me, therefore, in the investigation of your " first principles of arrangement," to ascertain what distinction you, who are so apt to charge dissenters from your maxims with the height of folly, make between artificial systems and the natural one. It would be curious, if he who blames others "for not fully appreciating the difficulty" of this subject," should happen to have promulgated his principles before he had made himself acquainted with the above distinction. 
You say "division and separation is the end of the Artificial System ;" and as I know not what particular artificial system you allude to, far be it from me to say that you may not possibly be in the right. But then you proceed as follows :"To establish agreements is the end of the Natural System." Now that you who kindly offer to "prevent young Naturalists from being prematurely embarrassed in this difficult subject," should thus express yourself, surprises me not a little; for I had always understood that so far from the natural system having for its object to establish agreements, its agreements have remained established from the time of the creation. I will not suppose that a writer "on systems and methods" could have forgotten to make himself master of the very keystone of his subject, and that he can still remain ignorant of the Natural System itself being the end or object at which we aim, and not an instrument like any artificial system to arrive at an end. It is no doubt for the purpose of displaying your powers of abstract reasoning that you advance such positions as the above, or that you state that the Artificial System is a descending series, and the Natural System an ascending one. Nay, what is more extraordinary than all, you seem in another place to imagine, that there are more natural systems than one, and that a variety of them have been already attained by the Linnean Society; for you advise us to "take any natural system, and see if this," \&c. Pray let me know where I shall find one of them, and I shall be content. It excites your surprise that " many modern Naturalists have not adopted your truths," but you ought to have recollected that the many are not so far advanced as yourself. They have been looking for one natural system, only one, and confined as their aim is, they have not as yet been able to attain it.

"It is the prevalent error of modern Naturalists to attempt to generalize where they ought to analyse, while their arrangements called natural, are almost all framed with a view to distinguish." Metaphysically, perhaps, this passage is -very clear; but what, in the name of plain sense, is the meaning of it? Modern Naturalists err in refraining to analyse, and also err, inasmuch as they are all busy distinguishing! Perhaps; however, after all, there is consistency in this paradox; for we have seen that you censure as well those who subdivide the Linnean genera as those who combine them into larger groupes. It was possible, nevertheless, for you to have expressed yourself with greater clearness, if this be really the meaning of so contradictory and curious a sentence.

You next draw "6a diagnosis" between M.M. Brown and Decandolle, which, because perhaps I am no Botanist, I can- 
not pretend altogether to understand; for the latter is blamed for "attempting fresh combinations at every stage," and the former praised "as his object is chiefly synthesis." I am the nore sorry for my ignorance of the botanical difference between combination and synthesis, not merely because I have myself the highest opinion of Mr. Brown's science, but because $I$ of course must feel interest in any eulogy of our friend by those who, as Botanists, must be best able to judge of his merits.

I have already hinted, that your distinction between the natural and an artificial system, making the latter a descending series, and the former an ascending one, could have only been maintained by you from love of paradox; but as you return to this distinction, and may therefore possibly believe it correct, I shall explain myself more fully. ' Both kinds of system afford ascending and descending series. It is clear, for instance, that the Linnean sexual system in Botany was in the first case founded as much on the examination of individuals as if it had been the natural system. In studying, therefore, any system, whether natural or artificial, we must always begin with individuals, and look upwards, discovering first the species, next the genus, and so on. It is true, indeed, that the genus may have been a more comprehensive groupe with early Naturalists than with modern; but however this may be, the above is the general process of investigation. Nay, it so happens, that this system of combining has hitherto been pursued principally in various artificial systems, although the searchers after the natural system have no reluctance to apply the knowledge of natural groupes, that happens -sometimes to be thus acquired, to their own more particular object. In the same way the natural system is not essentially an ascending series, for it is equally true, whethér it ascends or descends; being equally the plan of the Deity, however we may please to study it, whether by analysis or synthesis.

Next you say, "If we find a large genus agreeing in some well-marked characters of structure, form, station, and properties, it appears contrary to the end proposed by the natural system to divide and subdivide the species into small groups, and to give each of these the same value as is now possessed by the whole. This is frittering away characters which are essential to the use of a genus, and destroying our power over it when we wish to generalize." On this passage. I would first remark, for the third time, that the natural system proposes no end, but is itself the end proposed; next I would say, that no one, except yourself; ever indulged the idea of giving the same value to a part as to the whole; that neither you nor I can possibly know a priori what characters are es- 
sential to the use of genera, so as to deny the propriety of their being subdivided; and lastly, that so far from your power being thus destroyed when you wish to generalize, the genus remains, although possibly under another name, a groupe as much connected as before, and as much in your power for further combination, or even in a greater degree, inasmuch as by the more accurate examination of it in the process of subdivision, you must have become more definitely acquainted with its external limits, and its interior typical qualities.

Allow me here to ask two questions. First, Have you in your voluminous investigation of genera never broken up a Linnean genus? Secondly, How is it that you, who object to the combination of genera, should now complain of your power over them being destroyed when you wish to generalize?

Entomologists have to regret, that you, who in so kind and polite a manner have pointed out their defects, should not have attempted to remedy them. The only specimen which as yet you have given of the depth of your researches in this branch of Natural History, is your declaration, that Entomology is "a kingdom of Nature," and that the Linnean genus Scarabrus is an insulated groupe, which it would be the height of folly to subdivide! There is some merit in making your debut in a science with only two observations, and taking care that they should be both original and new. Certainly the having proposed such two solitary improvements, not only denotes your acquaintance with the subject, but well entitles you to decide that " Entomology requires the most skilful arrangement to enable the student to determine the multitude of species," and that " it is, nevertheless, unquestionably the worst furnished with assistance in this way." This may, no doubt, be abstractedly quite correct ; but there is no one who lays down "first principles of arrangement" in Entomology, excepting yourself, who will consider it to be the height of folly to subdivide a groupe like Scarabæus, of more than 2000 known species, and, in leaving the mass in chaotic confusion, thereby think that he is giving the most skilful arrangement for enabling the student to determine them. Were you indeed to take another glance at two common English insects, viz. Cetonia aurata and Trox sabulosus, I should not be surprised if you changed your opinion as to the best mode of enabling the student to determine the species.

I had long thought that there was but one Natural System in the world, and that every created being formed a part of it; but you say, "Take any natural system, and see if there is not always a remainder of unknown things." But if the natural system be that of God, what is meant by a remainder N.S. Vol. 6. No. 33. Sept. $1829 . \quad 2 \mathrm{E}$ of 
of unknown things? Not surely that $\mathrm{He}$ did not understand the relations subsisting between the things $\mathrm{He}$ created. And as to the Naturalists not understanding them, this only proves that we have not yet attained the knowledge of the natural system, and much less that of many of them. "We are constantly approximating to the truth, but never reaching it." At the same time it must be allowed, we are sometimes too apt to forget that the real object of the Naturalist ought to be to come as near the truth as possible, and that this is not to Je "done by " abstract reasoning," so much as by observing and arranging facts.

We next have a rather novel proposition started; to wit, that " the mammiferous animals are arranged with more ease, according to a natural system, (again as if there were more than one,) in consequence of their number being comparatively small, and their forms strongly marked." That is, in other words, the more widely the species are asunder, and the more distant they are in form, the more easily are they combined : just, perhaps, as a chain is more connected in proportion to the number of links that are wanting!

In order to prove that you have not confined your studies to the vegetable kingdom, you afterwards infer that the series of M. Cuvier in the Règne Animal, is the natural system. This author indeed says as much in his title-page; and you only think it necessary to criticize his groupes of Pachydermata and Passeres, and to prefer Jussieu's method of having for surch unknown things a miscellaneous groupe at the end of the work. As neither Passeres nor Pachydermata are much more cunknown" than other beings, it would perhaps save trouble, and give more satisfaction, to make one miscellaneous groupe of the whole of organized matter.

You decte that " those persons, who imagine it to be necessary or advantageous to find a place for every thing, appear to Lose sight of the chief object of the natural system, and to destroy its utility as an instrument of general reasoning." So then, the Natural System, or plan by which the Deity regellated the Creation, is nothing more, in your opinion, than in enstrument of general reasoning towards attaining a particular object. You are constantly alluding to this object, but what it is you de not deign to state; nor do you explain how they who endeavour to find a place for every thing destroy the utility of your instrument of general reasoning. But the defect, whout doubt, is on my side, and results from my being one of those practical Naturalists who would attempt to make accumulations to scrence without the aid of such abstract reasoning. 
Your reflections on the French school are, no doubt, intended, by their severity, to give us all due warning. I much question, however, whether the present perverse generation will not continue with the French to observe and arrange facts, dividing and subdividing them, rather than take with you a free and lofty range by issuing forth "first principles of arrangement" founded on abstract reasoning.

Although I am, as you are aware, no Botanist, I am glad to acquire any information on plants, and I confess your assertion, that Parnassia and Linncea are as distinct as any of the classes of vegetables, is quite new to me. Still more am I interested by your observations, that " in many instances a class is equivalent to an order or genus," and that "the great division of Cotyledonous plants may only be equivalent to the Order of Grasses." I do not now wonder that in another part of your paper you should place Natural History in diametrical opposition to Mathematics, for I recollect that Euclid begins with the fundamental axiom, that "the whole must be greater than its part."

You are obliging enough to consent to the adoption of the terms species and genus in Natural History, but to these alone. All other terms: for groupes are $\varepsilon \pi \varepsilon \alpha$ rreposvra, "fleeting instruments of thought." But how the term genus, or even species, is not equally objectionable, how it is not equally a fleeting instrument of thought, as well as the terms Class, Order, Family, \&c., I cannot well discover. In the place of these last terms you would, in the natural method, employ the words Groupe, Section, and Division; but I have yet to learn the ground of preference. Groupe is a general word for all masses of individuals, of whatever degree; and as to the words Section and Division, it surely requires explanation how they can express "assemblages of approximations" better than the terms Tribes and Families.

I have now gone through your Paper, of which, as I said at the beginning of my review, the object aimed at may, for all that I know, coincide with my own opinions. It is indeed the peculiar advantage of the style of argument you have chosen to adopt, that the purport and aim of your remarks remain enveloped in secure mystery, while the only visible points of your line of attack are detached and insulated propositions. Many of these detached propositions I am far from fighting with; many indeed are truisms; while many, such as those discussed above, will require some time, I suspect, before they can possibly triumph. But whether assented to or denied, I confess I do not perceive the use of any of them, and the novelty of but very few. Believe me, I do 
not say this in any spirit but that of good will. I do not feel indeed, except that I happen to have followed in the wake of such idiots as Fabricius and Latreille, and have subdivided Scarabeus, that any one of your observations personally affects me; and I can never forget that you have always, in the most honourable way, been a friend to the free expression of opinion, and have of late most warmly patronized Zoology. Yet as every law-giver must, in these days, expect to have the goodness of his laws examined before they are adopted, and as it is the duty of every lover of truth to sift them well before he allows them to pass current, I have judged that you would not be displeased if I, although from a very remote quarter, should return them to you for a little amendment. You know that the days of demigods and despotism in science have for ever gone by, and that by publishing your "principles," you stipulated for criticism.

Your object may possibly be to clear the way for the reception of a system of your own; for I observe that you find fault both with the Linnean and Jussieuan schools of Botany, although you appear to prefer the former. I observe, also, that no system of Zoology hitherto propounded, meets with your approbation. You have, therefore, with just confidence taken a wide range for your "first principles of arrangement," and I assure you I shall be glad to hear that your talents are employed in the application of them to observed facts. You must indeed be aware that such an application of your principles will tend more to give them weight in the eyes of $\mathrm{Na}$ turalists than your most abstract reasoning or profound metaphysics; however to slight these last may argue the height of folly. It really, however, appears to me high time now to let every one have his own way in Natural History; and in the spirit of toleration to let the Linnean enjoy his twelve words, colons, and specific differences, while you publish your asterisk system, and the obstinate heretics continue to wallow in the mire of natural groupes and subdivisions. Persecution, I fear, only serves to wed these last unfortunate wretches to their guilt, and, moreover, is perfectly useless trouble, inasmuch as we may be sure that the world will swim in the orthodox channel at last.

I remain, dear Sir, \&c., W. S. MacLeay. 